\title{
22. A New Method for Artificial Germination of Cotton Pollen.
}

\author{
By Sadamasa Hutukaiti.
}

Institute of Agronomy, Faculty of Agriculture, Tokyo Imperial University.

(Comm. by S. Ikeno, M.I.A., Feb. 12, 1942.)

Introduction. It will be perhaps no need to say that the informations of the pollen germination will give much help for the carrying of plant crossing, and from this point of view, the growth of pollen tubes on certain media has been hitherto intensively studied in a large number of plants. There have, however, been hitherto only two cases of successful experiments about the germination of cotton pollen and the results were $50 \%$ germination at most (Badamy 1922, Shibuya 1939). Since quite recently, the author has got better results in this matter ${ }^{1}$, he will give below an outline of his method.

One $\mathrm{day}^{2}$, the media prepared for the test of germination made up of $4 \%$ agar mixed with sucrose were left alone over night for certain reasons. The next morning, the dried media were washed with water and some pollen grains were placed on them immediately. After several hours, the author found to his astonishment the fact that more than $70 \%$ pollen grains germinated and some showed the elongated tubes. One of the results is given in Table 1 .

TABLE 1. The germination of pollen on the media left alone over night.

\begin{tabular}{l|c|c|c|c|c|c}
\hline $\begin{array}{l}\text { Concentration of } \\
\text { sugar (mol) }\end{array}$ & 0.0 & 0.2 & 0.4 & 0.6 & 0.8 & 1.0 \\
\hline $\begin{array}{l}\text { Number of pollen } \\
\text { grains tested }\end{array}$ & 543 & 632 & 641 & 1361 & 962 & 804 \\
\hline $\begin{array}{l}\text { Number of pollen } \\
\text { grains germinated } 3 \text { ) }\end{array}$ & 0 & 14 & 200 & 956 & 686 & 260 \\
\hline $\begin{array}{l}\text { Percentage of } \\
\text { germination }\end{array}$ & 0 & 2.2 & 31.2 & 70.2 & 71.3 & 32.3 \\
\hline
\end{tabular}

Preparation of medium. Considering the conditions for the success of germination above mentioned, the following method was planned and tested. After cooling completely by leaving alone in air about 3 minutes, a thin layer of agar contained sugar in Petri dish was dried by an electric fan for definite hours and then little destilled water was added to moisten the surface uniformly. Excess of water was taken away immediately (within 1 minute) with a blotting paper.

1) “Kanno No. 1", a selected line of upland cotton was used as material.

2) September 10th, 1941.

3) The pollen was decided to have germinated, when its growing tube reaches more than $2 / 3$ of its diameter. 
Germination of pollen grains. Pollen grains were placed on the media as soon as the preparations were finished, and their upper surface was turn over on little water to keep them from drying. The observations on growing pollen tubes can be done at the bottom of dish. When the concentration of suger in the medium was high $(0.6-0.8 \mathrm{~mol})^{1)}$, and the degree of dryness is suitable, the pollen grains swelled at once and seems as if it might soon burst out; and then they began to contract in a few minutes. Simultanously the pollen tubes were growing into the medium (Fig. 1).
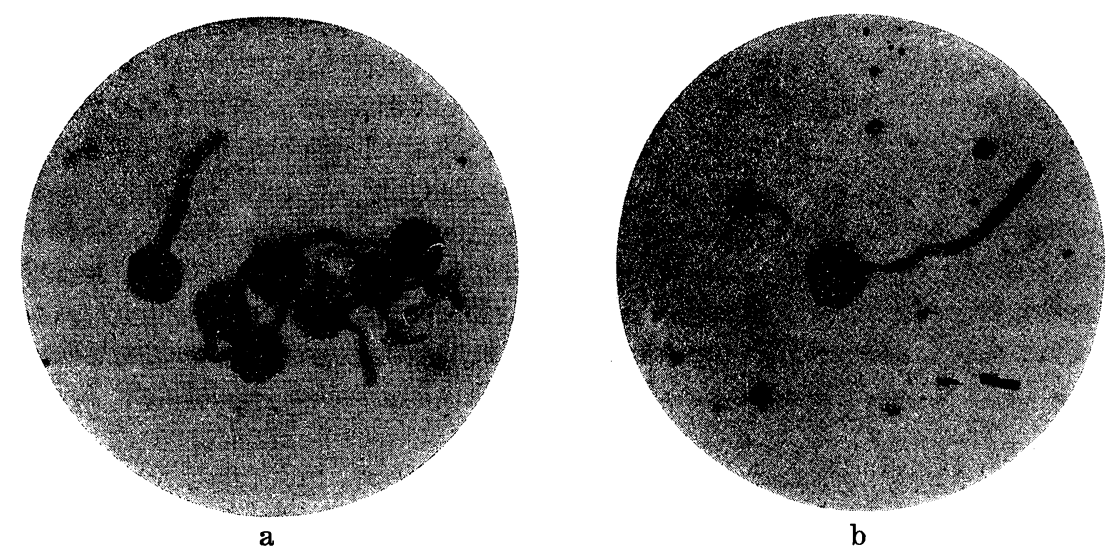

Fig. 1. The germination of cotton pollen on the medium prepared by the new method. a-all pollen grains producing equally pollen tubes. $\mathrm{b}-\mathrm{a}$ single pollen grew very long, about $500 \mu$, pollen tube.

The results of germination on the medium prepared by the new method will be given in the following table, in which the fact is apparent that two hours treatment with an electric fan is a suitable condition for germination, but the over-drying of agar is not.

TABLE 2. The germination of pollen on the media prepared by the new method.

\begin{tabular}{|c|c|c|c|c|c|c|c|c|c|}
\hline \multirow{2}{*}{\multicolumn{2}{|c|}{$\begin{array}{c}\begin{array}{c}\text { Concentration of sugar } \\
(\mathrm{mol})\end{array} \\
\text { Hours of drying }\end{array}$}} & \multicolumn{4}{|c|}{0.6} & \multicolumn{4}{|c|}{0.8} \\
\hline & & 2 & 3 & 4 & 5 & 2 & 3 & 4 & 5 \\
\hline \multirow{5}{*}{ 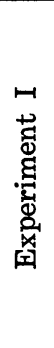 } & $\begin{array}{l}\text { Number of pollen } \\
\text { grains tested }\end{array}$ & 926 & 928 & 612 & 497 & 786 & 793 & 582 & 703 \\
\hline & $\begin{array}{l}\text { Number of pollen } \\
\text { grains bursted }\end{array}$ & 49 & 29 & 0 & 0 & 43 & 0 & 0 & 0 \\
\hline & $\begin{array}{l}\text { Number of pollen } \\
\text { grains germinated }\end{array}$ & 631 & 570 & 0 & 0 & 509 & 42 & 0 & 0 \\
\hline & $\begin{array}{l}\text { Percetage of } \\
\text { germination }\end{array}$ & 68.1 & 61.4 & 0 & 0 & 64.7 & 5.3 & 0 & 0 \\
\hline & $\begin{array}{l}\text { Length of pollen } \\
\text { tubes's) }\end{array}$ & 26.5 & 21.8 & 0 & 0 & 21.0 & 7.0 & 0 & 0 \\
\hline
\end{tabular}

1) The low concentration of sugar induced the pollen bursting at germ pores because of excess of moisture.

2) Average value denoted by the ocular micrometer unit; the diameter of pollen (air dry condition) is 7-8 units. 


\begin{tabular}{|c|c|c|c|c|c|c|c|c|c|}
\hline \multirow{2}{*}{\multicolumn{2}{|c|}{$\frac{\begin{array}{c}\text { Concentration of sugar } \\
\text { (mol) }\end{array}}{\text { Hours of drying }}$}} & \multicolumn{4}{|c|}{0.6} & \multicolumn{4}{|c|}{0.8} \\
\hline & & 2 & 3 & 4 & 5 & 2 & 3 & 4 & 5 \\
\hline \multirow{5}{*}{ 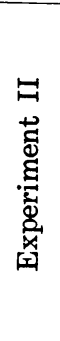 } & $\begin{array}{l}\text { Number of pollen } \\
\text { grains tested }\end{array}$ & 935 & 685 & 813 & 704 & 577 & 640 & 811 & 594 \\
\hline & $\begin{array}{l}\text { Number of pollen } \\
\text { grains bursted }\end{array}$ & 35 & 55 & 0 & 0 & 19 & 0 & 0 & 0 \\
\hline & $\begin{array}{l}\text { Number of pollen } \\
\text { grains germinated }\end{array}$ & 493 & 394 & 63 & 0 & 323 & 0 & 0 & 0 \\
\hline & $\begin{array}{l}\text { Percentage of } \\
\text { germination }\end{array}$ & 67.1 & 57.5 & 7.7 & 0 & 55.8 & 0 & 0 & 0 \\
\hline & $\begin{array}{l}\text { Length of pollen } \\
\text { tubes }\end{array}$ & 29.9 & 19.6 & 8.0 & 0 & 19.0 & 0 & 0 & 0 \\
\hline
\end{tabular}

Mechanism of germination. The water which moistens the surface of medium is absorbed at first by the pollen grains, which consequently swell up as much as they can; if the amount of water is too much, the pollen grains might burst at last. When they once touch the agar containing sugar, they begin to contract on account of the removal of water to get the equilibrium between pollen and medium. The force caused by the contraction would lead the pollen to germination. Of course, too much sugar is not good as the condition of germination because of inducing the excess of contraction. So that the proper concentration of sugar in the medium may be regarded as the main factor to promote the germination of pollen.

These experiments were carried out in the middle of September, at the end season of flowering, so the percentage of germination might perhaps have been greater by the use of more active pollen in the main flowering time as well as by the improvement of the method in the future.

\section{Literature cited.}

1) Badamy, V. K. 1922. Rep. Mysore agric. Der. 1922-3. (Quoted from Banerji 1922).

2) Banerji, I. 1929. Agric. Journ. India. $24: 332$.

3) Shibuya, T. 1930. Journ. Soc. Trop. Agric. 2:120. 